\title{
Workplace multilingualism in shifting contexts: A historical case
}

\section{FLORIAN HISS}

UiT-The Arctic University of Norway

Published in: Language and Society 46.5 (2017), pp. 697-718.

https://doi.org/10.1017/S0047404517000628

\begin{abstract}
:
This article investigates linguistic diversity, migration, and labour in the case of a nineteenthcentury copper mine in the multilingual northern periphery of Norway. Taking a historical perspective on workplace multilingualism, it reveals the dynamic relationships between the economic interests and policy-making of an industrial enterprise and the political and sociolinguistic development in a multilingual region, at a time when national authorities introduced assimilation policies. Owned and managed by British industrialists, the mine recruited almost exclusively migrant workers to a remote fjord in the Norwegian periphery, many of them Kven from northern Finland and Sweden. In a multi-layered approach, the study sketches multilingual work practices, policy-making, and the discursive positioning of diversity, and explores the company's management of the relationships between capital, community, and nation-state. It reveals the company's flexible approach towards diversity governed by economic interest.
\end{abstract}

(Workplace multilingualism, mining, Kven, Norway, historical)*

\section{Introduction}

This article investigates linguistic diversity, migration, and labour in one particular historical case. The background setting is Finnmark County in northern Norway in the nineteenth century. Situated 
north of the Arctic Circle, in the northernmost periphery of Europe, and only sparsely populated, the region has been multilingual for centuries. As in other parts of Europe, the nineteenth century was an era of major social, cultural, and political changes, such as the emergence of nation-states, industrialisation, and rapidly increasing geographical and occupational mobility. Rising nationalism and modernism put diversity and multilingual traditions under pressure.

The article examines the language policies and linguistic and discursive practices surrounding the region's first large industrial enterprise, a copper mine by a remote fjord near today's town of Alta. The British directors of the Alten Copper Works (ACW) recruited a diverse workforce that consisted almost exclusively of migrants: miners and expert workers from southern Scandinavia and Cornwall and, not least, a large number of Kven from northern Finland and Sweden.

For several reasons, the ACW and its mining population are an exciting case for investigating language policies and practices in a historical workplace setting. First, the mine was situated in the multilingual periphery of Scandinavia during a transition period from prenationalist to nationalist politics. Several ethnolinguistic groups had been living multilingually side-by-side. Now, the Norwegian state introduced systematic assimilation policies.

Second, the ACW displays many of the same relationships between capital, workers, state, and community as many mining enterprises today. Because many natural resources are found in peripheral regions, mining requires the mobility of workers, often profiting from social and economic problems in other regions (e.g. Godoy 1985; Bell 2012; Heller, Bell, Daveluy, McLaughlin, \& Noël 2016). Typically, the capital is situated somewhere else in the global economy, outside the legislation of the territory where the resources are extracted (Hechter 1975; Ballard \& Banks 2003). As in our case, mining in peripheral regions often involves minorities or indigenous groups (Godoy 1985; Ballard \& Banks 2003). These relationships correlate with centreperiphery relationships and sociolinguistic relations, and they are organised and mobilised in discourse. 
Third, in an era of political, cultural, economic, and technological changes, the ACW directors became active policy makers and brokers between national politics, migrant workers, and the surrounding communities. Against the agenda of national politics, they protected their employees from assimilation policies and supported linguistic diversity. With economic success as the primary rationale, their engagement in diversity issues displays manifold ways of positioning. The company knew how to exploit the linguistically diverse situation to their advantage: Maintaining ethnolinguistic diversity among the workers (contrary to national policies) helped them to keep wages down and secure a flexible supply of labourers.

Finally, there is a growing number of studies on workplace multilingualism under the shifting conditions and neoliberal regimes of the late twentieth and early twenty-first century as well as a long tradition of research into linguistic minorities. Work and economy have been acknowledged as important domains here (e.g. Fishman 1991), but we know little about the impact of economic activities and labour in such sociolinguistic contexts. Since a major part of the historical correspondence and other documents have been preserved, the case of the ACW offers a great opportunity to extend the view on historical workplace multilingualism and to investigate the role of labour in the face of greater language political shifts.

In my approach, I focus on three central aspects of the relationship between multilingualism and society: language practices, the management of language and diversity, and attitudes and stances vis-à-vis these. I relate these to the relationships between capital, state, and community, which seem pivotal in mining contexts (Ballard \& Banks 2003).

Language was a central means of social organisation and articulation in the there-and-then historical settings; but it is also the channel through which we as researchers engage with historical conditions (Fabian 1971). I build my argument first and foremost on original letters from the ACW's directors and administrators. Accessing these historical texts requires a critical awareness of the processes of genesis (Nevalainen \& Raumolin-Brunberg 2012). This includes both the wider contexts as 'meaningful conditions for the emergence, production, and exchange' of discourses 
(Blommaert 2005:125-26) and the development of and relations between individual voices, positions, and stances (Fabian 1971; Meeuwis 1999).

The article therefore begins with the wider context and gradually narrows down towards such situated, individual stances. It starts with an overview of the historical, geographical, and sociolinguistic contexts necessary for understanding the developments in and around the mine. Next, the case of the ACW is introduced and related to research on language, labour, and resource extraction. The relationships between language and labour, capital, state, and community are then analysed on three levels: (a) multilingual work practices and local organisation; (b) the management of diversity and human resources; and (c) the discursive positioning of company, community, and nation-state within particular intersubjective relations and contextual conditions. I give special attention to the role of the Kven workers as both migrants and a constitutive part of the mining community. The final section draws together the findings of all three levels.

\section{Historical, geographical, and sociolinguistic contexts}

Finnmark in the nineteenth century has been described as a frontier (Brox 1984; Aas 1998; Niemi 2009): a borderland region seen as a dynamic territory open to colonisation and new settlements. The region was inhabited by three ethnolinguistic groups: Sámi (about $50 \%$ of the population), Kven, and Norwegians (about 25\% each) (Niemi 2009). Sámi and Kven are Finno-Ugric languages (and thus significantly different from the Scandinavian national languages). Today, both are endangered. The Sámi are the indigenous population of northern Scandinavia, Finland, and the Russian Kola Peninsula. Though many Sámi were living in the area, only a few became employed by the ACW.

The Kven have their historical roots in present-day northern Sweden and Finland (see map in Figure 1). Kven people had been migrating along traditional tracks to and from the Finnmark coast for centuries. Particularly in the eighteenth and nineteenth centuries, many settled down in the 
coastal areas (e.g. Niemi 2003). Norway recognised Kven as a national minority language in 2005. Kven is related to northern Finnish dialects, but has developed independently over time with little contact with the southern centres in Finland. Historical definitions of the Kven differ from today's conceptions of a national minority. The ACW directors described the Kven as "Swedish and Russian Subjects who speak the Finnish language; of which both nations, according to our laws, are similarly foreigners" (see example (8); Finland was part of the Russian Empire).

Multilingual development in northern Scandinavia has been described in three main historical stages (Niemi 2008; Huss \& Lindgren 2010:261-62): (i) an era of varying traditional multilingualism, (ii) an assimilation period, (iii) and ethnic renaissance. The transition between the first two periods goes hand-in-hand with other political developments: the consolidation of the Norwegian nation-state, which was founded in 1814; the perceived need to protect national borders in the northern periphery (Eriksen \& Niemi 1981; Niemi 2009); and the shift from common land ownership through traditional use to internal colonisation and state ownership (Pedersen 1999). Sociolinguistically, culturally, and politically, these developments were central to the creation of northern Norway as a periphery (Niemi 2009; Pietikäinen \& Kelly-Holmes 2013); they show many of the economic, political, and social mechanisms of internal colonisation (Hechter 1975). Minorisation and linguistic discrimination of the regional population were part of this process. In the years before 1860 , Norwegian minority politics expressed monolithic and pluralistic perceptions of cultural diversity (Eriksen \& Niemi 1981:22-23). Most families pursued traditional livelihoods such as farming, fishing, and reindeer herding. Multilingualism was mainly regulated by practical needs, mobility, and actual contacts. National assimilation policies became effective from the 1860s onwards. Because of their connection to Russian (Finnish) territories, the Kven were considered a threat to the security of the Norwegian nation (Eriksen \& Niemi 1981). The school system and, more generally, social and economic pressure were among the most effective tools of Norwegianisation. Norwegian dominated the domains of official life, including workplaces, which gained importance in the people's everyday lives. Under the direct or indirect pressure of the 
assimilation policies, many speakers of Sámi and Kven gave up their languages (e.g. Huss 2008; Lane 2010; Pietikäinen, Huss, Laihiala-Kankainen, Aikio-Puoskari, \& Lane 2010). These macrosocial processes, their effects, and instantiations are visible in the immediate surroundings of the ACW.

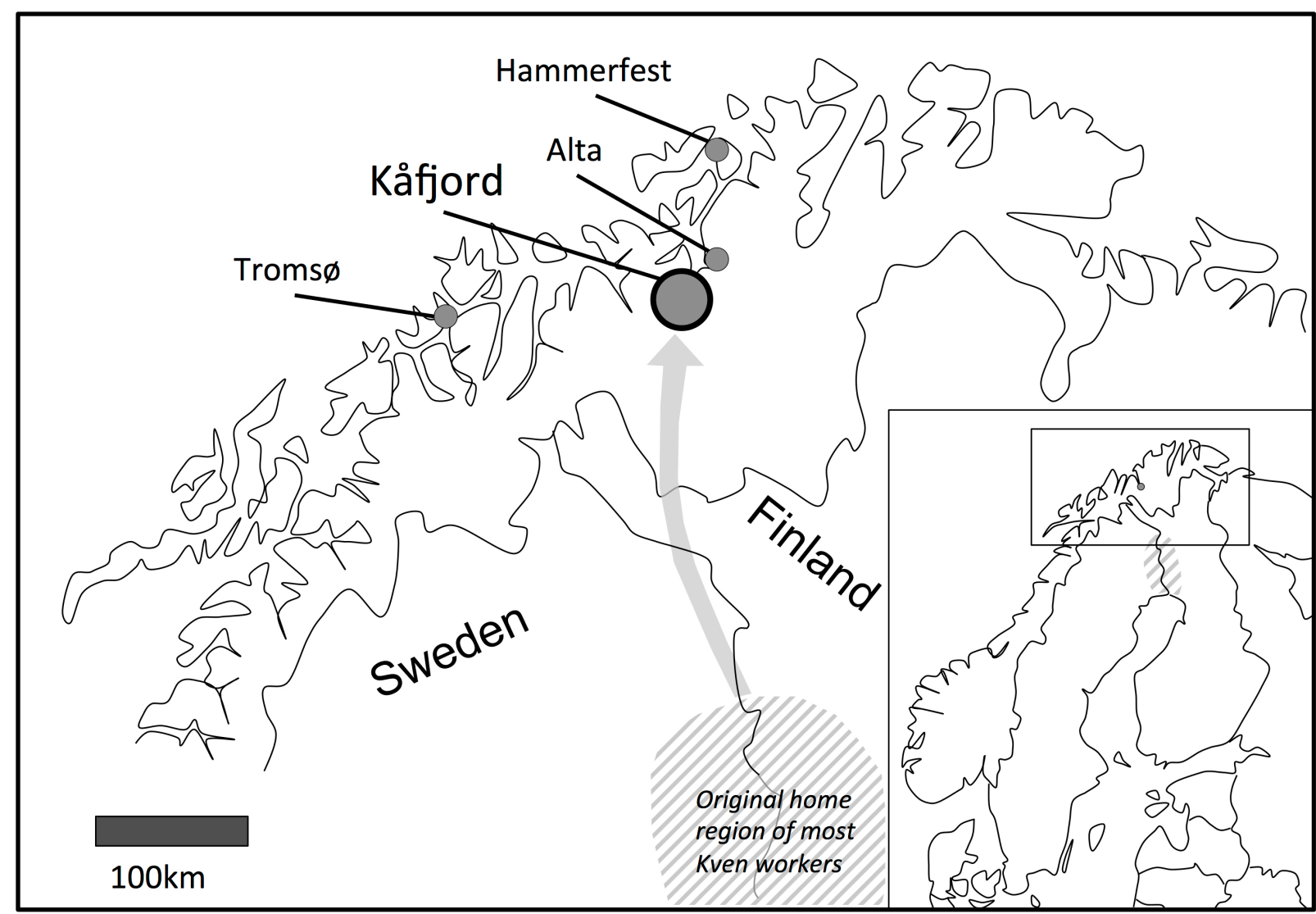

Figure 1: Northern Norway

\section{The ACW and its economic and social contexts}

John R. Crowe and Henry D. Woodfall, both British, founded the ACW in 1826. They had run a trading company in Hammerfest before and were familiar with the local conditions. A major part of the capital was subscribed by investors in London, powerful global players, who also owned mining enterprises in North and Central America (Nielsen 1990:354). This financial power gave the company a great advantage over local competitors and a strong position vis-à-vis the Norwegian authorities. That the ACW acquired the permission to extract ore in Kåfjord, an 'entirely deserted area of land consisting of mountains and rocks' (Crowe, quoted in Nielsen 1990:357, my 
translation) from the Norwegian government, disregarding local uses and traditions, reveals the typical centre-periphery relationships of internal colonisation (Hechter 1975:33; Pedersen 1999). The ACW mined copper ore and melted it into copper in Kåfjord until 1878. The mine was reopened by a Swedish industrialist in 1896 and finally closed in 1909 . Here I concentrate on the ‘English' period.

The ore in Kåfjord had a good quality, the surroundings offered plenty of waterpower, and the deposit was close to the fjord - good conditions for profitable exploitation. A major part of the copper was transported to British harbours, and coal for the melting house was shipped from Wales. Recruiting workers was a much bigger challenge. This is typical of many mining enterprises: Mining was labour-intensive and required the procurement of an ample and reliable supply of inexpensive workers (e.g. Godoy 1985), often in remote sites distant from the populated centres (e.g. Ballard \& Banks 2003:288). Recruiting labourers to remote places depends on economic or social problems in other, typically also peripheral, places (Bell 2012; Heller et al. 2016).

Few of the Sámi, Norwegians, and Kven in the area were interested in giving up their traditional livelihood to work in the dark and narrow mine. In the first years, the ACW recruited almost their complete workforce from southern Scandinavia and Cornwall (Drivenes 1985; Nielsen 1995, 1996). To attract miners to the North, they offered higher wages than their competitors. Many worked in Kåfjord for a while, just to return home as soon as they had earned enough money. In January 1833 , the directors conceded that these conditions would lead to "absolute ruin to the concern". Therefore, the arrival of Kven immigrants, escaping from a famine and diseases in their home villages and willing to work for much lower wages, meant an important turning point for the human-resource management and economic wellbeing of the company-which also explains the company's great interest in the Kven. Example (1) shows how the directors evaluated this situation in a report to one of the investors.

(1) Our snow is now rapidly disappearing, and we are preparing with some energy to make the most of the summer so that our returns and extended operations may not be probaded, for 
this purpose, I have engaged and shall continue to engage as many Quans as we can advantageously employ, the difficulty we have hitherto laboured under, and which is inseparably connected with any Enterprise of magnitude in Districts so scantily populated as this but more particulary in an undertaking foreign to the habits of the inhabitants is now fast weaving away, and the probability of our succeeding in creating a mining population in a great measure from among our Quans is placed beyond a doubt—Several families have now settled themselves and more are inclined to do so, and that they take to mining with alacrity, their competing with the Norwegians in the Tut Bargains is a proof - in the settings for this Month there are no less than 22 Quans that have taken, a greater feeling of cordiality likewise exists among them and the Norwegians. (ACW to A.F. Nellen, London, 21 April 1834)

The example expresses the directors' optimism and positive view of the Kven newcomers. It also gives an analysis of the company's situation and the district, as well as the integration of the Kven into the workforce. The new diversity is presented positively, combining competition with a mutual "feeling of cordiality".

From the early 1830s onwards, Kven workers constituted a major part of the workforce (see Table 1) and made Kåfjord the largest settlement in Finnmark.

\begin{tabular}{l|llllll}
\multicolumn{1}{r}{ Year: } & $\mathbf{1 8 3 5}$ & $\mathbf{1 8 4 0}$ & $\mathbf{1 8 4 8}$ & $\mathbf{1 8 5 5}$ & $\mathbf{1 8 6 0}$ & $\mathbf{1 8 6 5}$ \\
\hline Norwegians & 240 & 395 & 256 & 273 & 383 & 329 \\
Kven & 257 & 472 & 385 & 439 & 556 & 518 \\
Englishmen & 16 & 34 & 12 & 25 & 17 & 17 \\
Swedes & 26 & 85 & 85 & 94 & 108 & 89 \\
Russians & 12 & 5 & 3 & 5 & 3 & 3 \\
Germans & 10 & 11 & 4 & 1 & - & - \\
Sámi & - & - & - & 17 & 31 & 12 \\
Total & 568 & 1002 & 718 & 854 & 1098 & 968
\end{tabular}

Table 1: The mining population according to the ACW's original reports 


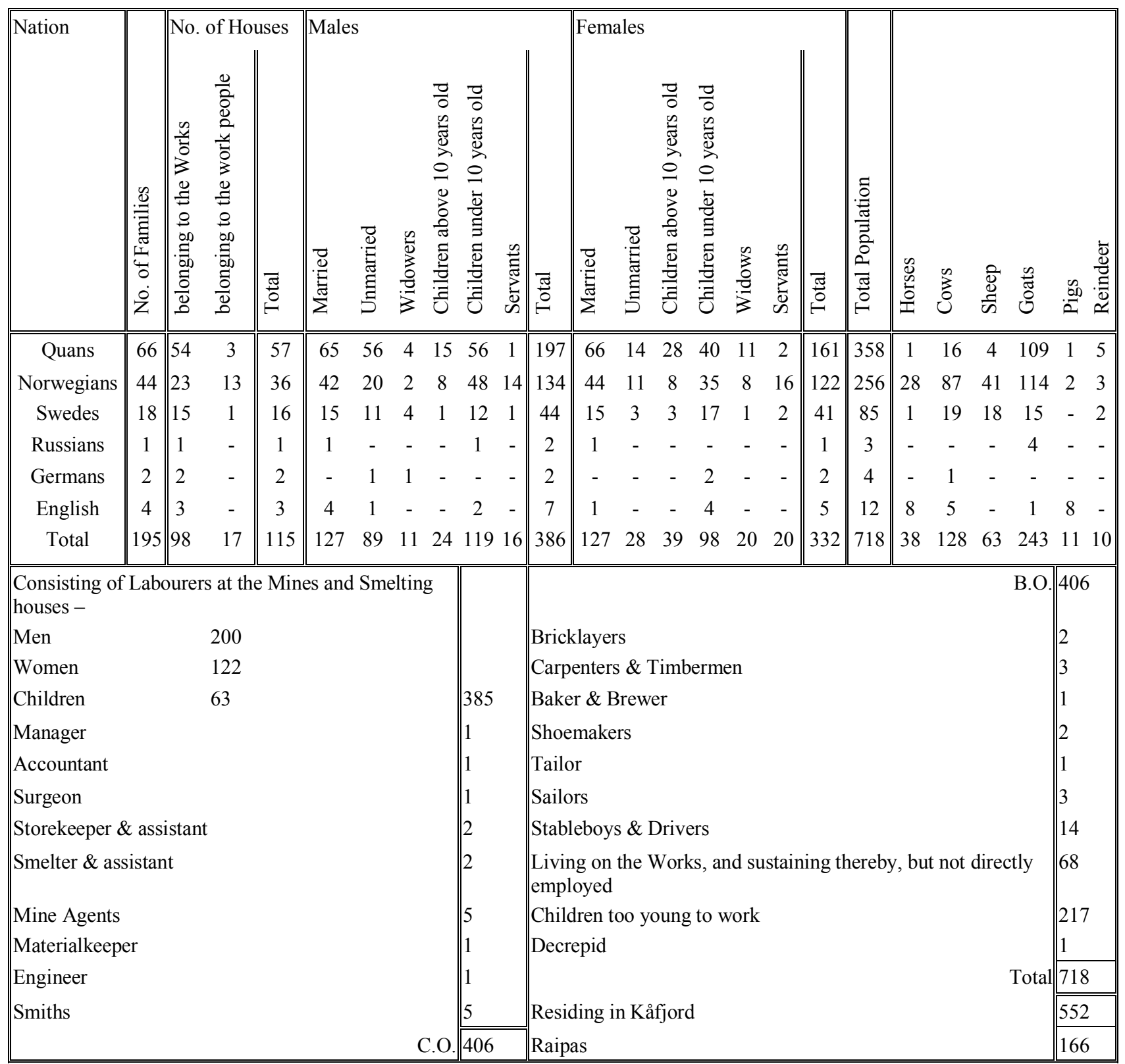

Table 2: The mining population in 1848 (reproduction from annual report)

As we see in Tables 1 and 2, the ACW directors categorised their workers according to nations. Nation was typically used for ethnic groups; with rising nationalism, it acquired the connotation of belonging to a nation-state (Niemi 2008:172-73). The category nation is presented prior to the distribution of professions; it even includes the animals kept by the families. In several cases, nation does not coincide with the country of origin. The Kven workers had arrived from Sweden and Finland (which was an autonomous grand duchy under the Russian Empire), but they were not listed as Swedes, Finns, or Russians. The most visible marker of ethnic difference is language. Language is also a central identifier in other contemporary definitions, for example, 'By 
Kven, we mean here the same who are called Finns in Sweden, that is, all those who speak the Finlandian or — as it is also called-Karelian language' (Stockfleth 1860:242, my translation). Thus, language was likely an important marker of group distinction in the mining community.

Here, the question arises whether the ACW used linguistic differentiation for strategic purposes. Heller et al. (2016) argue that cultural differentiation (rather than treating groups of workers in economic categories) is a strategic tool for companies to break up diverse workforces; in other words, it enhances intra-group relations (making it risky for individuals to abandon group structures) and weakens their bargaining position vis-à-vis their employer.

That the Kven newcomers pushed down the salary level was not appreciated by the other miners (Nielsen 1996:19-20), which adds economic aspects to the differentiation of groups. The ACW erected a separate Kven settlement on the opposite side of a bay. Nielsen (1996:27-28) interprets this as an attempt to prevent conflicts between Kven and Norwegians. However, the original documents do not give a clear explanation. Niemi (2003) argues that the foundation of the Kven village was an attempt to offer the (economically valuable) Kven workers ideal living conditions and make them stay in Kåfjord. School education in Kven offered benefits for the Kven families — and it made Kven women available as cheap workers in the mine.

The Kven were treated as an inherent part of the mining population and, simultaneously, as foreigners. The ACW needed a stable workforce, but was also interested in keeping some Kven mobile, as surplus labourers in the busts and boosts of seasonal and economic cycles (Godoy 1985; Heller et al. 2016). Being peripheral in the nation-state and in the investors' global networks, the ACW developed into a regional industrial centre. As such, it entered into new centre-periphery relationships with the surrounding communities, especially in the Kvens' home areas, which ensured the supply of workers and competition among them (cf. Hechter 1975:33). 
Multilingualism in the mine

The core material for this study consists of the company's correspondence from fifty-two years of mining operation, archived in the regional state archive in Tromsø. Usually, one of the directors stands as the author, but the handwritings vary. Some documents were likely written by other administrative staff. The files contain fifty to 400 letters in English and Norwegian per year, with an increasing number of Norwegian texts, covering various genres and topics, such as financial transactions, political and legal concerns, and economic and geological reports. I searched the material for texts dealing with language and diversity. Three types of texts attract attention here:

(a) Reports to the investors in London. These routine communications typically cover a broad range of issues, including the economic situation, mining operations, and a brief section about the workforce.

(b) Letters to authorities and clergymen in the home communities of the Kven workers. Issues of diversity arise here in connection with social welfare issues.

(c) Letters to Norwegian authorities and clergymen concerning diversity politics, education, and religion.

The major distinction between these texts is the way they construe the relation between sender and recipient - and how they position (particularly) the Kven workers within this relationship. The texts analysed later in this article are representative of these.

\section{Multilingual practices}

The original documents are instances of multilingual written-language practices; and they contain statements about the diversity among the employees. These provide rather indirect insights into multilingual practices. Direct comments about language use at work are rare — because work in the mine was first and foremost physical or because multilingualism was normal in the given geographic and historical context. 
The directors used their own multilingual skills to great advantage. Most letters are written in Norwegian or English, depending on the recipients. In either language, they employed elaborate techniques of persuasion and positioning appropriate to the social relations and communicational ends. The use of Norwegian and English side-by-side was key to their management work. Paulaharju (1928:99) mentions that Director Thomas (a successor of Crowe and Woodfall) had learned some Kven. A letter from 1857, in which he orders a Finnish grammar book, might confirm this. Beyond using English and Norwegian, Thomas may have seen a certain value in addressing his employees in their own ethnic language.

The workers in the mine were organised in small groups of four led by one experienced worker. Original documents show that members of all ethnic groups were assigned tasks as group leaders. It would be a likely explanation that the group leaders also functioned as language brokers (e.g. DuBord 2014). Example (2) suggests that during the first years, Kven and Norwegian workers were specialised in different tasks, but in later years Kven workers also specialised in technical mining and became foremen. The distribution of work tasks to different ethnicities likely helped to avoid language problems at the worksite, but it would also have reinforced differences between the groups (cf. van den Born \& Peltokorpi 2010:103-104 on ethnocentric recruitment and language policies in modern workplaces). Later, workers were also organised in mixed teams (Nielsen 1995:26).

(2) The want of a sufficient number of able \& suitable hands is the greatest difficulty we now have to contend with, and it is one owing to our peculiar situation we can only expect to get over progressively. Of late years the Quens or Finlanders come down in considerable numbers, but a small portion of them only become actual miners, they are however far superior workmen to the Norwegians as far as Gross work and common Labour in the Mine goes, but not for actual Boring \& Shooting; the some few who have been longer here and in a measure become settled take to Tutwork, on the other hand the Norwegians coming from a 
Mining District prefer the boring to casual work and are hard working Miners, tho' generally deficient in judgement and that experience which constitutes a good Miner, we have drawn them from the neighbourhood of Røraas \& Foldal and contemplate next spring calling for an additional number, which of course must be limited by the supply that come down from Finland and other circumstances which will always set bounds to the number we employ. (ACW's five-year report, 20 November 1835)

The case of an English miner in example (3), who was dispatched to a business partner in Trondheim, shows that the directors were aware of the communicational skills (and in this case, their pragmatic behaviour) of employees in certain key positions.

(3) Mr Netto leaves us by this Steamer, and will of course wait on you - as I have mentioned before, he is a good practical, as well as technical miner, and any report he may hand you, you may fully rely on; he is far, from sanguine, if any thing, for a miner, he is too cautious. How far he would suit you as manager at any of your works is problematical, as he has one very great fault, which I cannot disguise from you, and that is "an unfortunate temper" which little suits the Norwegian character — on all associations of this kind a spirit of harmony and goodwill must exist and be kept up, if a zealous cooperation in the service of the company is to be secured. Having said this much it remains for yourselves to judge of the propriety of engaging him. (ACW to H. Hoe \& Co., 4 August 1841)

Recommending Mr. Netto for the position of a manager depended not only on his professional expertise but also on his communicational behaviour in the linguistically and culturally diverse workplace. Multilingual skills are not mentioned explicitly, but it is obvious that Mr. Netto communicated with Norwegian-speaking colleagues. Some report lists reveal such a use of English and Norwegian (see Figures 2 and 3). 
Figure 2: Ore delivery (heading)

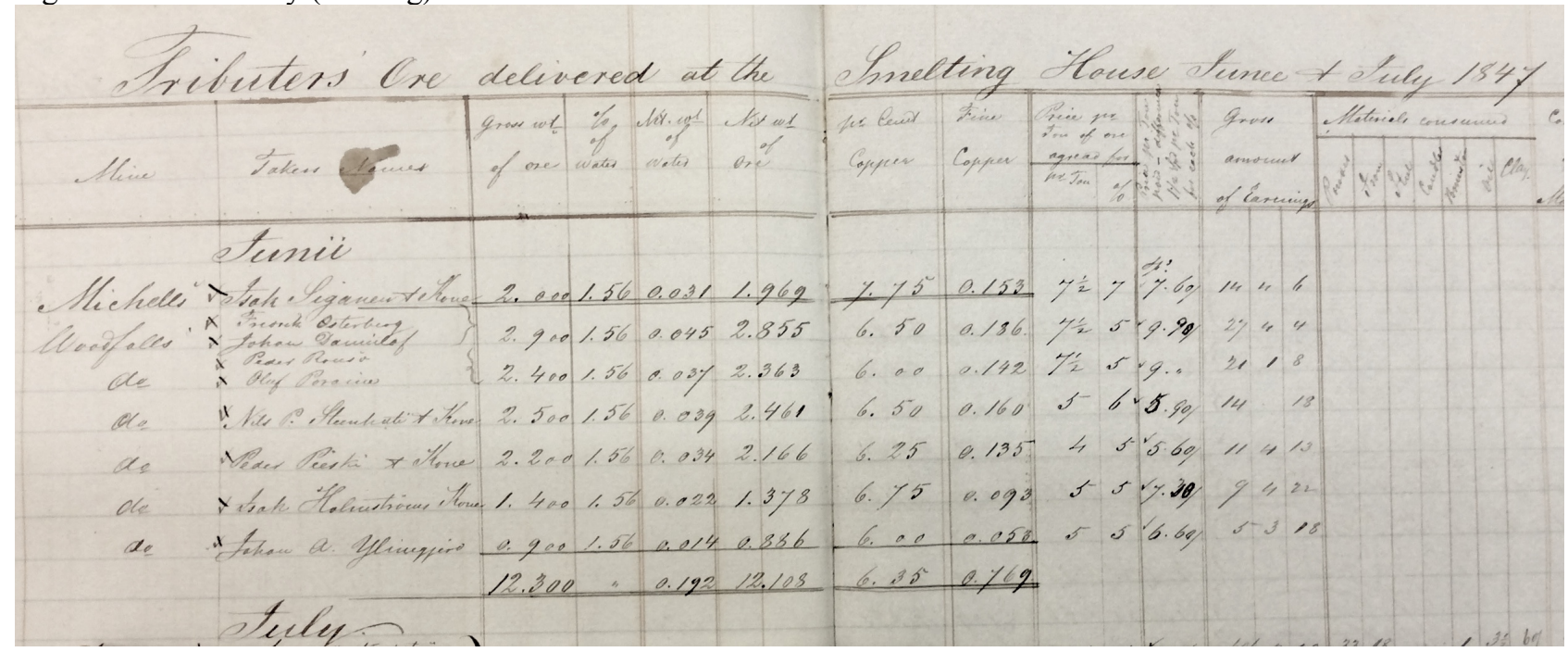

Figure 3: Ore delivery (content)

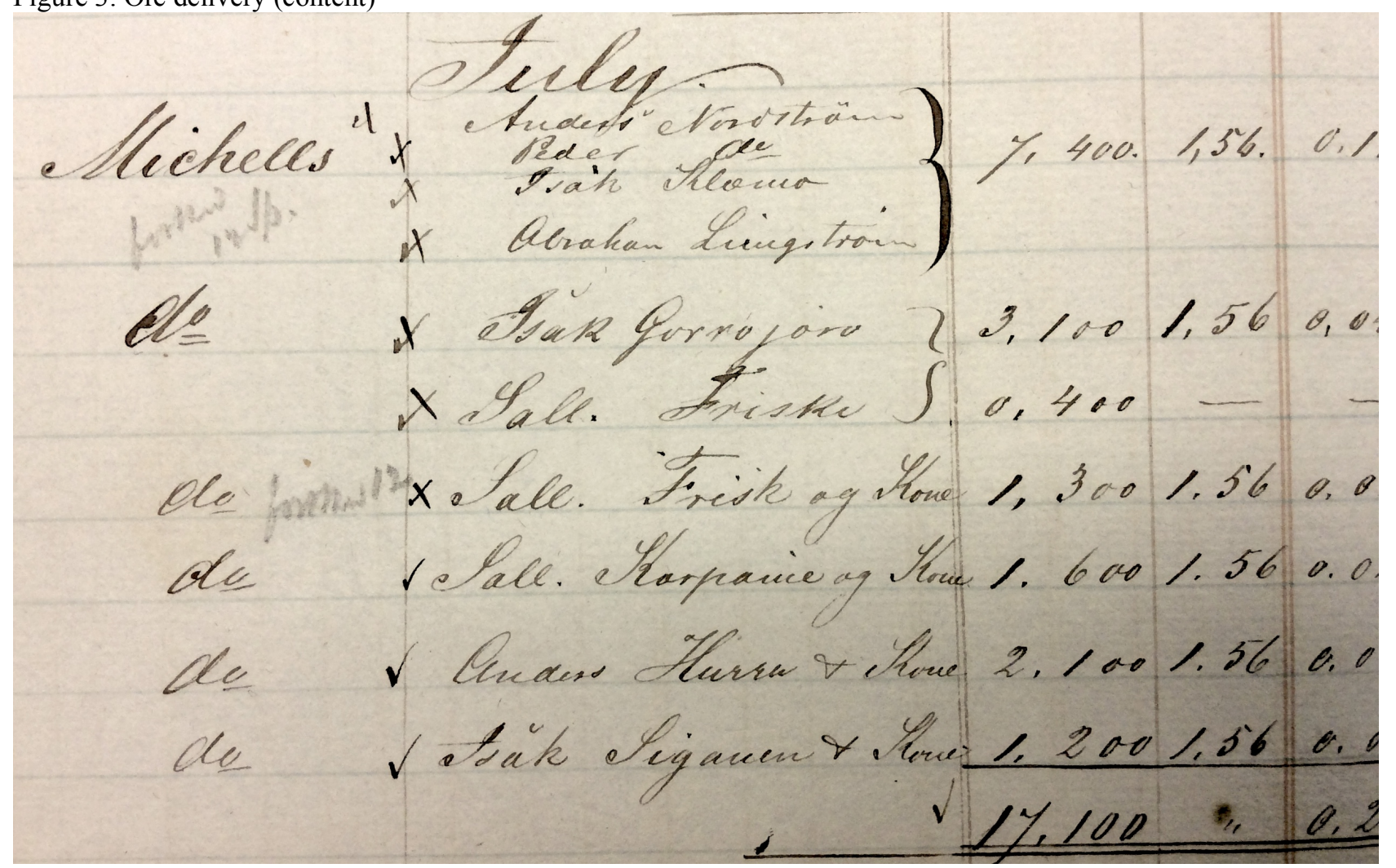

The overall linguistic frame of these documents is English. While the heading is in English

(Figure 2), the name column contains entries in Norwegian such as Sall. Karpaine og Kone 'Sall.

Karpaine and wife' (Figure 3). Such variation seems to have been a usual practice. Since Karpiaine is a Kven name, we may assume that Sallomon Karpiaine and his wife spoke Kven. A person using 
Norwegian registered their delivery of ore in an administrative system the main language of which was English. Similar practices can be observed in the archived correspondence: Headings and administrative notes are written in English; the language of the letters varies according to the addressees. This resembles practices in modern industrial companies_-with English as the main administrative language and lingua franca, local languages as means of everyday communication, and blue-collar workers using a variety of other linguistic resources (e.g. Gunnarsson 2014). Often, such practices contribute to the maintenance of hierarchies and competition among the employees (e.g. Angouri 2013; Angouri \& Miglbauer 2014).

Paulaharju (1928:99-101), who interviewed some remaining miners in the 1920s, reports isolated Kven loanwords such as tiikeri ('steiger, foreman', from Norw. stiger) and pankkihuone ('hammering house/room', from Norw. banke 'hammer' and Kven huone 'house/room'), where especially Kven women separated malmisteini ('orestone', from Norw. malmstein) from kroosteini ('greystone', from Norw. gråstein). These are likely outcomes of regular language contact among the workers.

Despite limited information on language use in the mine, the historical documents present a picture of varied multilingual practices. The material does not mention any company policies aiming at language use in work situations.

\section{Managing diversity in the mining community}

The question of how and with what purpose the ACW regulated multilingualism and diversity points us to the confrontation of the company's interests with national policies. While Norwegian authorities introduced assimilation policies, the ACW actively supported the linguistic diversity among their workers. These efforts were not aimed at the workplace itself but at the miners' public and private lives. 
The directors were in frequent contact with authorities and clergymen about issues concerning education and church services (see also Nielsen 1995, 1996; Niemi 2003). Clergymen, such as Nils Vibe Stockfleth, held a pluralistic conception of culture and wanted to offer Christian education and church services to all parts of the population in their respective ethnic languages. They recruited a Kven-speaking teacher for the workers' children, who was paid by the company. As a consequence, many workers were literate in Kven. This collaboration was not grounded in pure idealism on the part of the company. In a letter to Stockfleth, Crowe was quite explicit about his motives: His argument against assimilation builds upon the view that "the Kven are an eager, effective, industrial and thrifty people" as well as "their advantage in a national economic respect" (quoted in Stockfleth 1860:246, my translation).

Crowe maintained that the Kven showed a strong commitment to their own language and traditions (see also example (9)) and that it would be wrong to force them to adopt a foreign language, customs, and traditions. He withheld that the Kvens' rootedness to their home villages was an advantage for the company. As example (4) shows, moving back and forth, the Kven could serve as surplus labourers in the seasonal boost and stagnation cycles. Example (2) mentions also "other circumstances" with an impact on the need for workers. These include geological conditions and the market price for the extracted copper.

(4) There is another advantage resulting from the back and forth migration of these Kven that one has not honoured enough till now. The roughness of the climate combined with the shortness of the days reduces the need of workforce during the four winter months. There would arise a difficulty to provide subsistence to a population of workers without work, but the Kven solve this problem themselves, as most of those who have not settled down, visit their home during winter time and return in spring, thereby releasing the District from providing subsistence to an amount of people during a season where the opportunity for 
gainful employment is difficult. The journey home costs the Works about $1 \frac{1}{2} \mathrm{Spd}$. (Stockfleth 1860:245, my translation)

The ACW's strategy was twofold. On the one hand, to have them available as workers, they tried to make Kåfjord attractive for the Kven. Protecting them against the pressure of linguistic assimilation, erecting a separate Kven settlement, and offering school education were part of this strategy. On the other hand, it was in the company's interest that the Kven maintained strong connections to their home villages (and returned there when not needed in the works).

Norwegianisation was not desirable, because it aimed at cutting the Kvens' roots to their country of origin. In addition, as examples (1) and (9) show, the directors held the view that maintaining diversity ensured an open competition among labourers and a safe supply of affordable workers. Despite such competition, the material does not provide explicit evidence that the company exploited (and therefore supported) linguistic differences to destroy solidarity between the workers (Heller et al. 2016). On the contrary, we find descriptions of strategies to "fraternise the different tribes"; example (1) stresses "a greater feeling of cordiality" among the Kven and Norwegian workers. Competition between ethnolinguistic groups of workers was an advantage for the company; but they were aware of negative effects and tried to maintain a balance to ensure an effective production: "I am afraid under any circumstances the competition that would arise between English and Norwegians would be far from having the usual beneficial effect that under other circumstances might be expected" (ACW to W. and H.B. Ward, 23 March 1833). In any case, we see close interrelations between the company's commitment to language policy-making and their management of human capital. The company knew how to use the linguistically diverse situation to their advantage.

A few contemporary reports reveal the impact of the ACW's policies on language diversity in Kåfjord. Friis (1861) noted in his ethnographic map that the mining population in Kåfjord included approximately a hundred Kven families, where few individuals spoke Norwegian, and 
about thirty Norwegian families where all were capable of speaking Kven. According to Stockfleth (1860), the Kven in Kåfjord had not learned much Norwegian. When school inspector Killengreen documented the progress of Norwegianisation in 1886, he was satisfied with the learning and use of Norwegian in Kåfjord school (Killengreen 1887:26). The number of Kven pupils at that time was eight (of a total number of twenty-seven). Thus, the closing of the mine in 1878 had a major impact on the linguistic situation in Kåfjord. Besides the national assimilation policies, the emigration of many Kven workers was the main reason for the rapid language shift among the remaining inhabitants. The decline of the mining activities caused a new wave of Kven migration (Nielsen 1995:346; Niemi 2003). Many Kven miners found work in Michigan's Copper Country in the US (e.g. Alanen 2014:59-62).

\section{Discursive positioning and social relations}

The ACW managers were also managers of diversity, not only by supporting multilingual school and church services. Diversity management includes who talks about diversity to whom in which way, and to what communicational ends. Let us therefore move from general policy-making to situated stances and diversity management in correspondence between the ACW and representatives of capital, state, and the workers' home communities. Vis-à-vis the investors, the ACW had to account for the work progress in the mine; the ACW and representatives of the Kvens' home communities held each other financially responsibe for social welfare payments; and Norwegian authorities pursued the national project while the ACW tried to give direction to state policies and avert negative effects for the Kven workers and the company. The company's relationships towards these differ in terms of roles, power, and accountability. In all examples, the Kven (as a group or as individuals) are part of the letter content. They are positioned in a triangular relation vis-à-vis the mutual alignment of writer and addressee, such as sketched in Du Bois's (2007) stance triangle (subject 1 - subject 2 - evaluated object) or Östman’s (e.g. 2005) principle 
of implicit anchoring towards self, interactional relationships, and culture. The discursive positioning of the Kven is thus part of the writer's positioning vis-à-vis the addressee, which involves the given (macro-social) relationships between the ACW and the addressees (including financial and political power and centre-periphery relationships) as well as specific communicational ends, such as accounting and persuasion. The picture of the Kven drawn in these letters must therefore be understood as positioned according to these conditions, stances, and intersubjective relations (cf. Fabian 1971; Meeuwis 1999).

Examples (1) and (2), and examples (5) through (7), are extracts from the ACW's reports to the investors in London. All reflect hierarchical relationships of economic power. The directors in Kåfjord were accountable to the investors for the economic situation in the mine. In these reports, the Kven are presented almost exclusively in economic terms, as human capital. We find collocations with economic terms such as supply (example (2)), advantageously, profitably (example (5)), advantage, afforded, selection (example (6)), and materially increased (example (7)).

(5) We have further engaged about a dozen Quains, as we may think we may be able to employ them advantageously now in Cobbing \& Spalling and I was unwilling to give too great a check to their finding work here, a considerable number have come down, but many have found employment in the Fishery which promises to be exceedingly productive, these Men can also be discharged should I find we cannot profitably employ them. (ACW to W. and H.B. Ward, 23 March 1833)

The dozen Kven mentioned in example (5) are the first of a wave of immigrants who became employed by the mine. While the directors seem still unsure about their economic value and account for their employment in careful tones, examples (1) and (6) are very explicit about their 
advantages. This is most visible in the writer's stance-taking: "the difficulties... are fast weaving away" (example (1)) and "I do not despair" (example (6)).

(6) We have had a greater number of Quans already come down than we are capable at this moment of employing to advantage. it has however afforded us an opportunity of making a selection, and as soon as the Snow leaves, and we can commence our gross work, we shall progressively engage others, at present there is certainly no appearance of there being any scarcity of hands but rather the reverse, and I do not despair, particularly as many have come down this year with their families, that ultimately we shall be able to form a permanent mining population. (ACW to A.F. Nellen, 22 March 1834)

That the Kven workers emerged as a valuable currency for the directors when aligning their position vis-à-vis the investors, becomes visible in their accounts of undesired developments. In example (7), the writer has to explain a delay in work progress (caused by bad weather, an epidemic, and the death of two workers). Expressions of affective and evaluative stance (including valuable, harassed, fortunately, great hopes) address economic responsibilities, rather than the miserable situation of the workers (and there is no mention of the fate of women or children). In practice, the workers are presented as material resources. The Kven are presented as part of the solution, which is important for the writer's position because it mitigates his responsibility.

(7) Altho' I say we are in full summer activity, we have not yet been able to turn our attention to Raipas or the discoveries beyond Mancurs. these lodes are situated so much higher than the scene of our main operations, that it is some weeks later before we can begin there, but this is not the sole cause, we have of late had so many of our men sick, no less than 30 or 40 at a time, and having so much preparatory work on hand, we really could not spare men for either objects altho' our number have been so materially increased by the Quans that have of 
late been engaged - my attention however will be given to these valuable points as early as possible, so many of our men being laid up has harassed me not a little, fortunately we have as yet only lost two of our male labourers, and as more settled weather may soon be expected, I am now in great hopes we shall return to our usual healthy state. (ACW to A.F. Nellen, 2 June 1834)

Examples (8) and (9) represent communications between the ACW and representatives of the home communities of the Kven (example (8)) and state authorities (example (9)). The ACW was not economically dependent on any of these. Thus, in both examples, its own economic power becomes a central argument. The reports to the investors follow a routine scheme, building on established relationships. Examples (8) and (9) use explicit metalanguage to position writer and addressee vis-à-vis each other and the particular topic of the letter. In example (8), the company refuses its responsibility for covering social-welfare expenses for Kven labourers and urges the addressee, a parish priest in Sweden, to reimburse these expenses. While the reports to the investors present the Kven workers as a valuable acquisition and a constitutive part of the mining population, example (8) highlights the distance between the company and the Kven. Negative properties of a single Kven person are ascribed to the whole group (lines 19, 24-26). The Kven are also explicitly identified as foreigners (line 6).

(8)

17 March 1840
Prost Zacharias Grape
Karungi

1Med störste Forundring har jeg lest en Attest fra Dem, sendt mig med Hr. Major Kuylenstjerna I Faveur af Fredrich Winola, 2hvori de foreslager at han, da han, medens han var i Verkets Tjeneste, har faaet en Skade, der setter ham ut av stand til at ernære sig, burde sendes hit for at nyde Understöttelser, ${ }_{3}$ og at Sockna Stemma af den Grund har undslaaet sig for at hjelpe ham4Da dette spörgsmaal foraarsaget megen Opmerksomhed og neppe kan være dem ligegyldig vil jeg med faa ord
${ }_{1}$ With the greatest surprise I have read an attestation from you, sent to me through Hr. Major Kuylenstjerna in favour of Fredrich Winola, in which you suggest that he, since he, while he was in the service of the Works, has suffered an injury, which makes him incapable of feeding himself, should be sent here in order to receive support, 3and that the parish council for that reason has refused to help him. ${ }_{4}$ Since this question caused great attention and can hardly be indifferent to you, I will with 
omtale de forskjellige Maader, hvorpaa denne gjenstand kan betragtes, för end jeg gaaer over til dette særegne Tilfelde. 5 Jeg formoder, De mave indrömme, at om Verket her og nogle faa Köbmend i dette Sogn og Hammerfest have havt nogen Fordel af Qvænernes Hidtstrømmen / 6 Qvæn er en almindelig Benevnelse her, der er felles for Svenske og Russiske Subjekter, der tale det finske Sprog, hvilke begge Nationer efter vore Lover ere ligemeget Udlændinger/ 7de Kirkesögne hvorfra de have emegreret have havt idetmindste ligesaa megen Fordeel 8 deels ved at være bleven befriet fra deres overflödige Befolkning, 9deels ved at en Deel er vendt tilbage, efterat have oplagt Penge her, 10deels endelig ved at have laant dem til deres Slektninge og Venner i deres Födeorden.

${ }_{11}$ De maa derfor tilstaae at vi i denne Henseende staar paa lige Fod, idet begge Partier ere tjente.

${ }_{12}$ Fremdeles maa de indrömme $130 \mathrm{~g}$ en saa bekjendt Sandhed kan ikke engang være de uvidende og taabelige Bönder af hvilke jeg formoder Eders Sockna Stemma er sammensat ubekjendt, ${ }_{14}$ at ligesom der ere faa onde her $i$ Verden, der ere ganske uden goder. ${ }_{15}$ Saaledes ere der faa goder uden deres Feil, og vi maae være takknemlige naar det gode qvid domminerer, 16hvilket, som jeg troer, begge Partier i det omhandlede Spörgsmaal maae tilstaae at være tilfeldet. ${ }_{17}$ Eders Sogne maa efter omstendighetene være uleiliget med Tilbagekomsten af en frisk mand som en invalid eller en Kone som en Enke $180 \mathrm{~g}$ naar de vil tilbagebetale dette Sogn og værket alle de Udgifter, de have været nödt til at bære, 19ved at begrave de Döde, helbrede de Syge, underholde de faderlöse og transportere tilbage til dered Födested gamle ubrugbare Folk, Spidsbuber, Landstrygere og Horer, 20da men ikke för maa de klage over at Kröblinger og Enker ere kastede paa deres Skuldre.-

${ }_{21}$ Men jeg maa henlede deres oppmerksomhed til et tredje Partie. - 22 De vil kalde tilbage i Deres Erindring ikke allene, at Mange, som ere komme herned ere Acquisitioner, der ingenlunde ere at tragte efter, mange netop det modsatte, men ogsaa, at 23om end skjønt Værkets Bestyrere og enkelte Kjöbmænd have fundet det fordeelagtigt at modtage unge og friske mænd af god Characteer, $24 \mathrm{endog}$ disse have været betragtede som et stort onde af vore Bönder og de norske Grubearbeidere ved Værket, 25 fordi de have nedsat Lönnen $260 \mathrm{~g}$ just dette tredje Partie, hvis Interesse umiddelbar har lidt ved Qvænernes Hidtströmmen, beskattes for at underholde dem ... a few words describe the different ways in which this issue can be viewed, before I proceed to this particular case. ${ }_{5}$ I suppose, you must admit that while the Works here and some few tradesmen in this parish and in Hammerfest have had some advantage of the streaming here of the Kven ( ${ }_{6} \mathrm{Kven}$ is a usual name here, which is common for Swedish and Russian Subjects who speak the Finnish language, of which both nations, according to our laws, are similarly foreigners), 7 the church parishes from where they have emigrated, have had at least a similarly great advantage, spartly by being relieved of their superfluous population, spartly because some have returned, after having saved money here, 10partly by having borrowed it to their relatives and friends at their birthplace.

${ }_{11}$ You must admit that we in this respect are standing in the same position, since both parties have profited. ${ }_{12}$ Furthermore you must also admit 13 and such a wellknown truth can't even be unknown to the ignorant and stupid Farmers of whom I assume your parish council is composed, 14that there are few bad things here in the World which are totally without benefits. ${ }_{15}$ Similarly there are few goods without their negative side, and we must be thankful when the good dominates, 16 which, as I believe, both parties in the subject matter must admit, is the case. -17 Your parish must under these circumstances be troubled after the return of a healthy man as an invalid or a wife as a widow 18 and when you are to refund this parish and the Works all the expenses they have had to bear, 19by burying the dead, curing the sick, supporting the fatherless and transporting back to their place of birth the old and unusable people, rogues, vagabonds, and prostitutes, 20 then, but not earlier, you complain that cripples and widows are thrown on your shoulders.-

${ }_{21}$ But I must direct your attention to a third party.${ }_{22}$ You might recall to your memory not alone that many who have come down here are acquisitions nobody would strive after, many precisely the opposite, but also that 23 though the managers of the Works and individual tradesmen have found it advantageous to welcome young and healthy men of a good character, 24 still these have been considered a great evil by our farmers and the Norwegian miners at the Works, 25 because they have pushed down the wages; 26and just this third party, the interest of which has suffered directly from the streaming-here of the Kven, will be charged for supporting them ... 
The writer shows his negative attitude vis-à-vis the addressee openly (lines 13,20) and contrasts the ACW's responsible work with the irresponsible behaviour of the community representatives (lines 17-20). The Norwegian miners and local farmers receive a key role in the writer's persuasion strategy (lines 24-26): While lowered wages meant a great advantage for the company, the writer now foregrounds the negative effects for the Norwegian workers - and holds the Kven responsible.

Example (9) is part of the ACW's political engagement vis-à-vis the state authorities. We saw earlier how the directors protected their workers against the impact of state policies (in particular linguistic assimilation). This letter argues against the restriction of the freedom of religion, but the message is the same: "In case of any change in their current freedoms and privileges one must fear [the Kven] would leave the country" (line 14). In his construction of a writer-addressee relationship, the writer plays out economic vs. political power. The Kven are neatly embedded in this relationship.

\section{November 1840 \\ Foged Lie! \\ Kongshofmark.}

${ }_{1}$ Den samme fölelse af Retsind som under almindelige omstendigheder vilde have afholdt os fra uopfordrede at meddele vor Mening om en Lov ${ }_{2}$ hvis Virkning maa have en Almindelig Indflydelse paa det hele Land, 3byder os efter opfordring frimodigen at ytre samme, $40 \mathrm{~g}$ saaledes er det at vi nu meddele vor anskuelse af Prof. Hjelms Forslag til en Kirke Lov 5som tilsigter at tilintetgjöre religiens frihed i Norge.

6I de faa betragtninger vi ansee det nödvendigt at gjöre, afholde vi os ifra enhver undersögelse af benevnt Forslags Details $70 g$ holde os kun til betragtningen af den sansynlige virkning som det vil have paa et District shvis nuværende Vigtighed for en stoor Deel vil erkjende at hidröre fra det Etablissement 9 hvis Bestyrelse vi have den Ære at være overdragne.

${ }_{10}$ Det folketal som gradeviis er trukken til stedet er af en blandt Characteer og indbefatter forskjellige former af den Christelige Religion. 11 Af dette Folketal ere den störste deel Queener, 12som ikke alene, ere hengivne til deres egen Gudsdyrkelse eller Gudstjeneste, 13men særdeles holdende paa deres offentlige Udövelse, $140 \mathrm{O}$ som man i tilfælde af nogen Forandring i deres nærværende Friheder eller Privilegier maatte befrygte
Bailiff Lie!

Kongshofmark.

1The same feeling of justice which under normal conditions would have prevented us from unrequestedly telling our opinion about a law ${ }_{2}$ the effect of which might have a serious impact on the whole country, sprompts us on invitation to forthrightly utter the same, 4and that is why we are now telling our view of Prof. Hjelm's proposal of a new Church Law 5 which aims at foiling the freedom of religion in Norway.

6In the few considerations we consider necessary to make, we refrain from any examination of the details of the mentioned proposal 7 and adhere only to the consideration of the presumable effect that it will have on a district sthe current importance of which to a great extent [you] will acknowledge to derive from the establishment the management of which we have the great honour to be assigned.

10 The population that gradually has moved here is of a mixed character and includes different forms of the Christian religion. ${ }_{11}$ Of this population the largest part are Kven, 12who not alone, are devoted to their own worship or divine service, 13but particularly standing on their public practice, 14and who in case of any change in their present freedoms and privileges one must fear 
vilde forlade Landet. ${ }_{15}$ Naar man siger at saadant onde vilde finde en Antidote i den mere udstrækkte mark, som vilde aabne sig for Benyttelsen af de Indfödte, ${ }_{16}$ Saa kunne vi alene henvise til Erfaringen som viser Ugyldigheden af en saadan Paastand $170 \mathrm{~g}$ Umuligheden af at fortsette Værket uden en tilstrekkelig opmuntring og paa en saadan Scala af Belönning 18 som alene aabne Concurrence kan tilveiebringe.

${ }_{19}$ Det er tillige alene Engelske Capitaler som have bragte Værket i dets nuværende heldige tilstand ${ }_{20}$ og hvorved Værket ogsaa for Fremtiden vil virke til Districtets Bedste ${ }_{21}$ og Bidrage til at forhöie dens Moralsk og politiske Vigtighed 22 som tilkommer disse nordlige Egne... would leave the country. ${ }_{15}$ If one says that such evil would find an antidote in the wider region, which would open itself for the use of the locals, 16 we could only point to the experience which shows the invalidity of such a claim and ${ }_{17}$ the impossibility to continue the Works without sufficient motivation and on such a scale of payment 18 which only open competition can provide. ... ${ }_{19}$ It is also exclusively English Capitals that have brought the Works into its current favourable condition 20 and through which the works also in the future will act for the district's best ${ }_{21}$ and contribute to increasing its moral and political importance 22 which benefit these northern tracts. ...

The writer addresses the state representative in a formally polite way, but with a number of hidden threats (lines 7-9, 19-21). On the surface, he takes an inferior position vis-à-vis the bailiff, but indirectly, he signals that the whole district (including the state authorities) profits from the success of the ACW. The Kven are indispensable for this success (lines 14-18). In comparison to example (8), it is striking how the Kven workers and the 'locals' are positioned vis-à-vis each other: The Kven are strongly desired and crucially important, while there is little value in the local population (as human capital).

Comparing these texts, we receive a complex and heteroglossic picture of the relations between the company, capital, state, and community. The contrasts between the stances and positioning of social relationships in each text underline the importance of looking into the intersubjective spaces within the greater, historical setting. Each text presents the relevant relations in a multi-voiced manner, positioned according to particular communicational ends. Together, these examples reveal a flexible and strategically adaptable attitude towards diversity and, in particular, the Kven.

\section{Discussion and conclusion}

Briefly summarised, we cannot see that the ACW implemented systematic language policies inside the mine. In the mining community and vis-à-vis the state authorities, the company supported 
diversity, often with great effort. In discursive practice, the directors show a flexible and strategic attitude towards their linguistically and culturally diverse workforce and the Kven immigrants. They could be positioned flexibly according to the social, political, economic, and intersubjective relations and strategic goals of particular communications.

The case of the ACW reveals close interconnections between the economic interests and policy-making of an industrial enterprise and the political and sociolinguistic development of a multilingual region. The ACW directors were brokers of this development vis-à-vis the community and the nation-state, with their own economic agenda. We can draw a multifaceted picture of the ways economic interests and ethnolinguistic diversity were managed within the relations between capital, nation-state, and community.

In the wider field, the findings can contribute to a more multifaceted picture of workplace multilingualism. The policy practices of the ACW clearly differ from the nationalist monolingual policies historically implemented by, for example, the Ford Company (Hewitt 2012) as well as the 'new centrality of language in late capitalism' (Duchêne \& Heller 2012:19), viewing multicultural employees as 'global business' untapped resource' (Fitzsimmons, Miska, \& Stahl 2011).

The flexible management of language and diversity was central to the ACW's management of their workforce. While contemporaries such as Stockfleth (1860; cf. also Nielsen 1995, 1996) described the ACW's treatment of their employees as philanthropic, the directors' correspondence with the investors, in particular, assigns to the workers a merely material value in the overall process of production (as analysed and criticised by Marx 1867). The overall strategy, it seems, was to ensure as much room for manoeuvre, flexibility, and access to human resources as possible-for best economic profit. Avoiding strict language policies is a means to ensure flexibility in modern workplaces as well (Angouri 2014).

Two interrelated aspects of the relationships between company, community, and nation-state are important: the (potentially conflicting) interests of the nation-state and capital and the dynamics of centre-periphery relationships. Duchêne \& Heller (2012) sketch a shift from national pride to 
economic profit in late capitalism. Our historical case reveals conflicts of interest between rising nationalism and early capitalism. Centre-periphery dynamics existed between the northern periphery and the Norwegian nation-state, between the ACW and the financial centre in London, and between the mine as an industrial centre and the wider region. The peripheral position of the mine made the recruitment of nonlocals necessary for economic success, which created new centreperiphery relationships. The ACW's diversity policies were a strategy for securing a solid and cheap supply of labourers. These policies were in conflict with Norwegianisation, which was mainly a policy of linguistic assimilation and an attempt to secure the nation in the northern periphery. The ACW's connection to the global financial centre changed the balance of the relationship between company and nation-state. These centre-periphery relations are not only part of the wider context; they are linked to sociolinguistic relations, discursively constructed, mobilised, and repositioned in the company's correspondence.

A perspective that takes into account the flexibility and situatedness of practices, policies, and stances within these relations is necessary, because competition, diverging interests, and collaboration occur simultaneously. Discursive positioning and persuasion were important parts of the company's creative engagement in these complex relationships which, in turn, were mobilised in discourse in the pursuit of particular strategic goals.

A prospect for future research is to investigate the reception and recontextualisation of historical cases such as the ACW within the multilingual settings of modern economy. There is no explicit marketisation of the ACW as authentic history (see, for example, Coupland \& Coupland 2014), but Kven immigration and traditional diversity have become part of a new narrative that seeks to build coherence between modern economic development, mobility, regional tradition, authenticity, and, not least, economic success.

\section{References}

Aas, Steinar (1998). North Norway: The frontier of the North? Acta Borealia 15(1): 27-41. 
Alanen, Arnold R. (2014). Finnish settlements in the United States: 'Nesting Places' and Finntowns. In Auvo Kostiainen (ed.), Finns in the United States: A history of settlement, dissent, and integration, 55-74. East Lansing: Michigan State University Press.

Angouri, Jo (2013). The multilingual reality of the multinational workplace: Language policy and language use. Journal of Multilingual and Multicultural Development 34(6):564-81. (2014). Multilingualism in the workplace: Language practices in multilingual contexts. Multilingua 33(1-2):1-9.

_,$\&$ Marlene Miglbauer (2014). ‘And then we summarise in English for the others': The lived experience of the multilingual workplace. Multilingua 33(1-2):147-72.

Ballard, Chris, \& Glenn Banks (2003). Resource wars: The anthropology of mining. Annual Review of Anthropology 32:287-313.

Bell, Lindsay A. (2012). In search of hope: Mobility on the Canadian frontier. In Pauline Gardiner Barber \& Winnie Lem (eds.), Migration in the 21st century: Ethnography and political economy, 207-46. London: Routledge.

Blommaert, Jan (2005). Discourse: A critical introduction. Cambridge: Cambridge University Press.

Brox, Ottar (1984). Nord-Norge: Fra allmenning til koloni [North Norway. From commons to colony]. Tromsø: Universitetsforlaget.

Coupland, Bethan, \& Nikolas Coupland (2014). The authenticating discourses of mining heritage tourism in Cornwall and Wales. Journal of Sociolinguistics 18(4):495-517.

Drivenes, Einar-Arne (1985). Fiskarbonde og gruveslusk [Fisherman-farmer and mineworker]. Tromsø: Universitetsforlaget.

Du Bois, John W. (2007). The stance triangle. In Robert Englebretson (ed.), Stancetaking in discourse: Subjectivity, evaluation, interaction, 139-82. Amsterdam: John Benjamins.

DuBord, Elise M. (2014). Language, immigration and labor: Negotiating work in the U.S.-Mexico borderlands. Houndmills: Palgrave Macmillan. 
Duchêne, Alexandre, \& Monica Heller (2012). Pride and profit: Changing discourses of language, capital and nation-state. In Alexandre Duchêne \& Monica Heller (eds.), Language in late capitalism: Pride and profit, 1-21. New York: Routledge.

Eriksen, Knut Einar, \& Einar Niemi (1981). Den finske fare: Sikkerhetsproblemer og minoritetspolitikk i nord 1860-1940 [The Finnish danger: Security problems and minority politics in the North 1860-1940]. Oslo: Universitetsforlaget.

Fabian, Johannes (1971). Language, history and anthropology. Philosophy of the Social Sciences 1(1):19-47.

Fishman, Joshua A. (1991). Reversing language shift: Theoretical and empirical foundations of assistance to threatened languages. Clevedon: Multilingual Matters.

Fitzsimmons, Stacey R.; Christof Miska; \& Günter K. Stahl (2011). Multicultural employees: Global business' untapped resource. Organizational Dynamics 40(3):199-206.

Friis, Jens Andreas (1861). Ethnographisk kart over Finmarken. No. 3 [Ethnographic map of Finnmark. No. 3]. Christiania: Videnskabsselskabet.

Godoy, Ricardo (1985). Mining: Anthropological perspectives. Annual Review of Anthropology 14:199-217.

Gunnarsson, Britt-Louise (2014). Multilingualism in European workplaces. Multilingua 33(1-2): $11-33$.

Hechter, Michael (1975). Internal colonialism: The Celtic fringe in British national development, 1536-1966. London: Routledge \& Keagan Paul.

Heller, Monica; Lindsay A. Bell; Michelle Daveluy; Mireille McLaughlin; \& Hubert Noël (2016). Sustaining the nation: The making and moving of language and nation. Oxford: Oxford University Press.

Hewitt, Roger (2012). Multilingualism in the workplace. In Marylin Martin-Jones, Adrian Blackledge, \& Angela Creese (eds.), The Routledge handbook of multilingualism, 267-80. London: Routledge. 
Huss, Leena (2008). Scandinavian minority language policies in transition. In Kendall A. King, Lyn Wright Fogh, \& Natalie Schilling-Estes (eds.), Sustaining linguistic diversity: Endangered and minority languages and language varieties, 129-43. Washington, DC: Georgetown University Press.

, \& Anna-Riitta Lindgren (2010). Scandinavia. In Joshua A. Fishman \& Ofelia García (eds.), Handbook of language and ethnic identity: Disciplinary and regional perspectives, 255-68. Oxford: Oxford University Press.

Killengreen, Jens (1887). Indberetning om en inspektionsreise til Finmarken. Foretaget $i$ Tiden fra 2den Februar til 7de Juni 1886 [Report of an inspection journey to Finnmark. Carried out in the time from 2 February to 7 June 1886]. Christiania: Fabritius.

Lane, Pia (2010). 'We did what we thought was best for our children': A Nexus analysis of language shift in a Kven community. International Journal of the Sociology of Language (202):62-78.

Marx, Karl (1867). Das Kapital: Kritik der politischen Oekonomi [The Capital: A Critique of political economy]. Hamburg: Verlag von Otto Meissner.

Meeuwis, Michael (1999). Flemish nationalism in the Belgian Congo versus Zairian antiimperialism: Continuity and discontinuity in language ideological debates. In Jan Blommaert (ed.), Language ideological debates, 381-423. Berlin: Mouton de Gruyter.

Nevalainen, Terttu, \& Helena Raumolin-Brunberg (2012). Historical sociolinguistics: Origins, motivations, and paradigms. In Juan Manuel Hernández-Campoy \& Juan Camilo CondeSilvestre (eds.), The handbook of historical sociolinguistics, 22-40. London: Blackwell. Nielsen, Jens Petter (1990). Altas historie, Bind 1: De glemte århundrene 1520-1826 [Alta's history, vol. 1: The forgotten centuries 1520-1826]. Alta: Alta kommune. (1995). Altas historie, Bind 2: Det arktiske Italia 1826-1920 [Alta's history, vol. 2: The arctic Italy 1826-1920]. Alta: Alta kommune. 
(1996). A miniature empire: The copper works at Kåfjord and the community that grew up around it. Alta: Alta Museum.

Niemi, Einar (2003). Kvenene i nord: Ressurs eller trussel? [The Kvens in the North: Resource or threat?]. In Einar Niemi, Jan Eivind Myhre, \& Knut Kjeldstadli (eds.), Norsk innvandringshistorie, Bind 2: I nasjonalstatens tid 1814-1940, 128-46. Oslo: Pax. (2008). Kategorienes etikk og minoritetene i nord: Et historisk perspektiv [The ethics of categories and the minorities in the North: A historical perspective]. In Fredrik Fagertun (ed.), Veiviser i det mangfoldige nord: Utvalgte artikler av Einar Niemi, 169-82. Stamsund: Orkana.

(2009). Grenseland og periferi: Møtested for stat, nasjon og etnisitet [Borderland and periphery: Meeting place for state, nation and ethnicity]. In Einar Niemi \& Christine SmithSimonsen (eds.), Det hjemlige og det globale: Festskrift til Randi Rønning-Balsvik, 431-55. Oslo: Akademisk publisering.

Östman, Jan-Ola (2005). Persuasion as implicit anchoring: The case of collocations. In Helena Halmari \& Tuija Virtanen (eds.), Persuasion across genres: A linguistic approach, 183212. Amsterdam: John Benjamins.

Paulaharju, Samuli (1928). Ruijan suomalaisia [The Finns of Finnmark]. Helsinki: Kirja.

Pedersen, Steinar (1999). Statens eiendomsrett til grunnen i Finnmark —en del av den interne 'kolonihistorie' [The state's right of land ownership in Finnmark — a part of the internal 'colonial history']. In Harald Eidheim (ed.), Samer og nordmenn: Temaer i jus, historie og sosialantropologi, 15-38. Oslo: Cappelen Akademisk Forlag.

Pietikäinen, Sari; Leena Huss; Sirkka Laihiala-Kankainen; Ulla Aikio-Puoskari; \& Pia Lane (2010). Regulating multilingualism in the North Calotte: The case of Kven, Meänkieli and Sámi languages. Acta Borealia 27(1):1-23. 
— \& Helen Kelly-Holmes (2013). Multilingualism and the periphery. In Sari Pietikäinen \& Helen Kelly-Holmes (eds.), Multilingualism and the periphery, 1-16. Oxford: Oxford University Press.

Stockfleth, Nils Vibe (1860). Dagbog over mine missionsreiser i Finmarken [Diary about my mission trips to Finnmark]. Christiania: Chr. Tønsbergs forlag.

van den Born, Floor, \& Vesa Peltokorpi (2010). Language policies and communication in multinational companies. Journal of Business Communication 47(2):97-118.

\section{Note}

*I would like to thank the Research Council of Norway (SAMKUL) for funding this research.

Address for correspondence:

Florian Hiss

Department of Language and Culture

Faculty of Humanities, Social Sciences and Education

UiT-The Arctic University of Norway

florian.hiss@uit.no 